Notas técnicas y científicas

\title{
CAMPANIAN-MAASTRICHTIAN LIMESTONE WITH LARGER FORAMINIFERA FROM PEÑA BRUJA ROCK (SANTA ELENA PENINSULA)
}

\author{
Baumgartner-Mora Claudia ${ }^{1)} \&$ Percy Denyer ${ }^{2)}$ \\ 1) Institut de Géologie, University of Lausanne, UNIL-BFSH 2, \\ Lausanne, Switzerland \\ 2) Escuela Centroamericana de Geología, Apdo. 214-2060 UCR, \\ San José, Costa Rica
}

\section{INTRODUCTION}

We report on a Upper Cretaceous (Campanian-Maastrichtian) limestone sample collected by P. Denyer and a group of students during a field trip of the course Geología de Campo II, of the Escuela Centroamericana de Geología (UCR). The sample was taken of the islet known as Peña Bruja, located near to the shore of Naranjo Beach, Santa Rosa National Park, in the southeast of the Santa Elena Peninsula in Northern Costa Rica (Fig. 1), Lambert coordinates $352.2 \mathrm{E} / 308.3 \mathrm{~N}$. Unfortunately only one small sample was furnished due to the difficult access of the cliff and the high waves and strong currents around the rock.

The sample was analyzed by Claudia MoraBaumgartner at the Institut of Geology of University of Lausanne. A polished thin section of $30 \mathrm{~mm}$ thickness was used for the observation under a petrographic microscope and for cathodoluminescence microscopy. Cathodoluminescence (CL) of the polished surface is obtained by the exposure to an electron beam produced by a cold cathode with an acceleration potential of $15 \mathrm{kV}$, in a vacuum chamber with a dilute He-atmosphere at 0.2 Torr. The CLequipment is attached to a conventional light

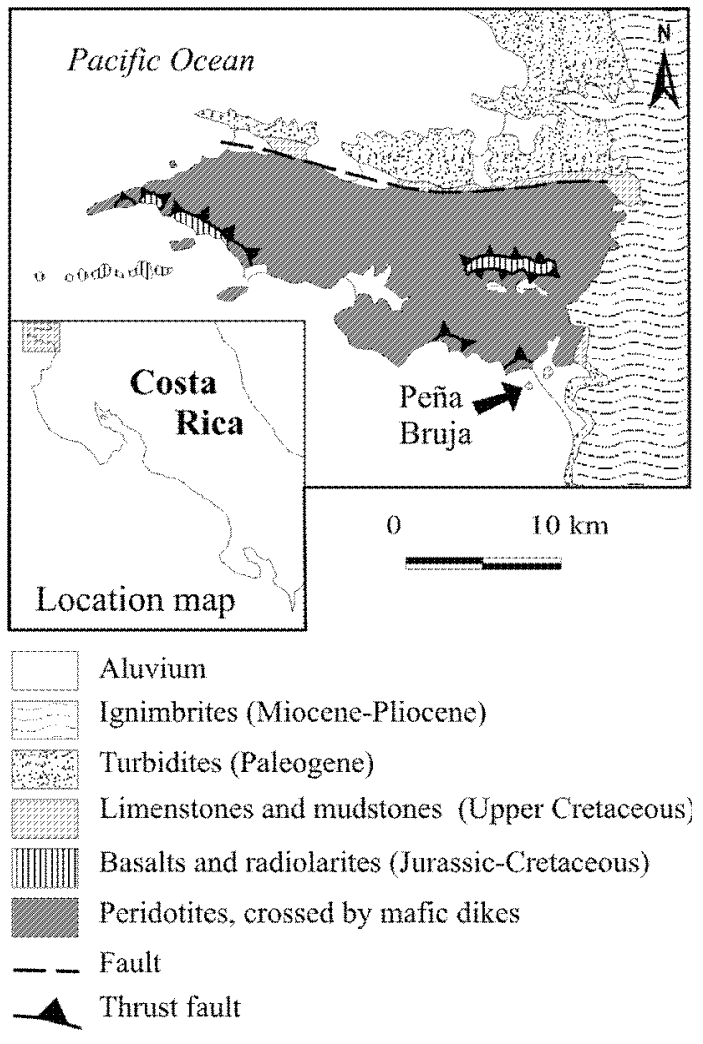

Fig. 1: Regional geological map and location (modified from Tournon \& Alvarado, 1997). 
microscope. Different CL-intensities in calcite correspond to variation in trace concentrations of $\mathrm{Mn}^{+2}$.

The field trip was sponsored by the project \# 113-90-071, Análisis geo-estructural comparado de Costa Rica financed by the Vicerrectoría de Investigación (UCR). We thank administration of the Área de Conservación Guanacaste for their valuable help. Dr. Jorge Cortés (CIMAR) gave logistic support during the field trip.

\section{GEOLOGIC SETTING}

The southern Santa Elena Peninsula is composed by ultramafic rocks. The nearest coastal outcrops are formed by the Santa Elena Ultramafic Nappe (mostly serpentinite) and by underlying rocks, which correspond to relative autochthonous Mesozoic sequence (breccias, basalts, and radiolarites). In the east part of the area (Fig. 1), the peridotites are directly overlain by El Viejo Limestone, composed by Cretaceous rudists, nerineas and corals (Schmidt-Effing, 1974; Burgois et al., 1984), and calcareous mudstone that overlay El Viejo (Burgois et al., 1984).

The northern part of the Santa Elena Peninsula is composed by Upper Cretaceous pelagic limestones, followed by Paleogene turbiditic sediments (Baumgartner et al., 1984). Upper Miocene-Pliocene ignimbrites unconformably overlie the sedimentary and igneous Cretaceous-Paleogene rocks.

The offshore Peña Bruja Rock (Fig. 2) consists of recrystallized bioclastic packstone containing larger foraminifera. This islet had been described as peridotite by Madrigal (1982). Tournon \& Alvarado (1997) mapped it (probably without sampling) as ignimbrites and acid tuffs. Using binoculars Chiesa et al. (1998) recognized the calcareous composition of Peña Bruja. These authours also described harmonic folds that we could not find, even from a short distance in a boat. Although we could not see any clear stratification, we estimated that this islet is formed by vertical striking N40E strata. Very clear fractures were observed on the northern side (Fig. 2).

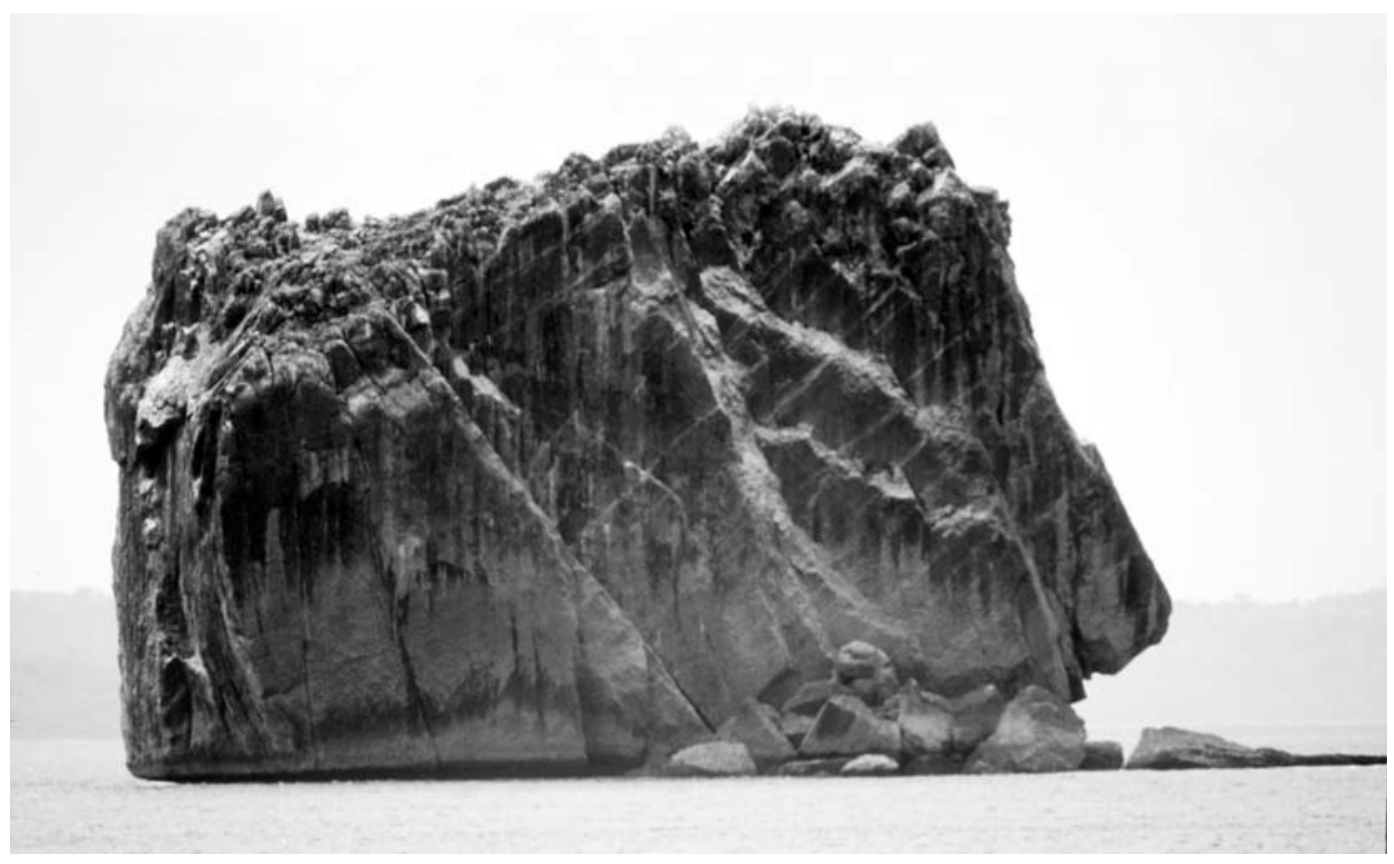

Fig. 2: Photograph of the Peña Bruja islet showing orthogonal fractures. The right side is offshore (southwest), the width is about $15 \mathrm{~m}$. 


\section{RESULTS}

The Peña Bruja limestone shows bright $\mathrm{CL}$ in the micritic reams around bioclasts (Fig. $3 \mathrm{~b})$ and in the recrystallized micritic matrix and cements (Fig. 3b), whereas most bioclasts show a dull CL (Fig 3b, 4b).

The sample consist of a hard, recrystallized bioclastic packstone. The skeletal material is primarily composed of larger and small benthic foraminifera, such as small rotaliids and few porcellanaceous forms, fragments of echinoids, red algae, dasycladacean green algae, and fragments of rudists. Some of

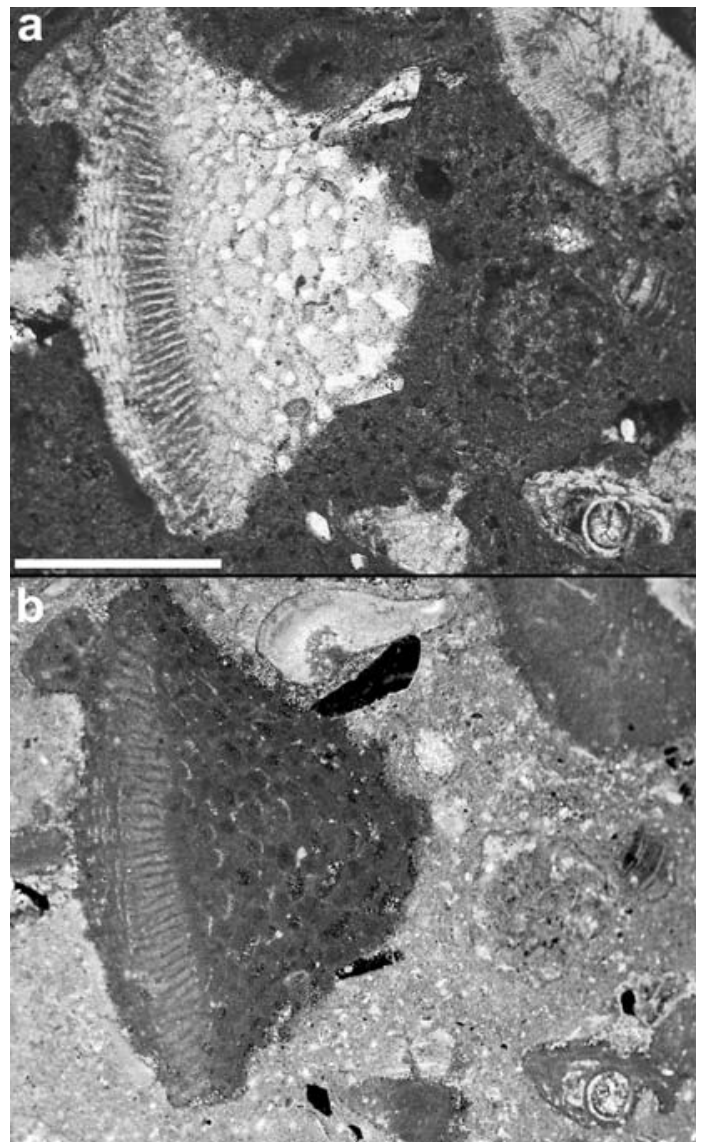

Fig. 3: a) Oblique vertical section of Pseudorbitoides sp. showing the pseudorbitoid radial plates and the lateral chambers.

b) Oblique vertical section of Pseudorbitoides sp. viewed under cathodoluminescence.

Scale bar for a and b represents $500 \mathrm{~mm}$. the angular and rounded clasts of serpentinite suggest the erosion of the Santa Elena Ultramafic Nappe as source. The larger foraminifera are biocorroded and/or eroded and bear a micrite rim possibly produced by microboring organisms. The bioclasts come from a variety of shallow water carbonate environments and were clearly reworked into a possibly offshore, and calm water environment evidenced by the abundant micrite in the sample.

Due to the size and the hardness of the sample only a few oblique sections could be observed; no isolated material could be obtained for oriented cuts. The larger foraminifera belong mainly to the genus Pseudorbitoides $\mathrm{H}$. Douvilléé (Figs. 3, 4).

We identified some specimens as: Pseudorbitoides rutteni Brönnimann (Figs. 5, 6),

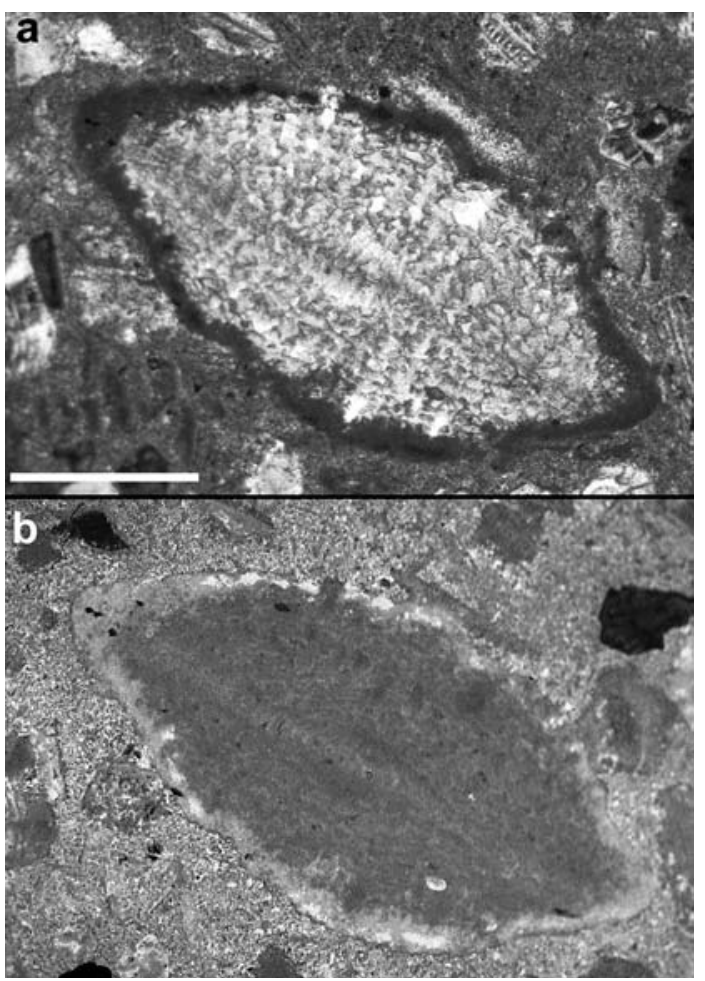

Fig. 4: a) Oblique vertical section of Pseudorbitoides sp. surrounded by micritic rims.

b) Oblique vertical section of Pseudorbitoides sp. under cathodoluminescence, the micritic rims are brighter than the micritic matrix.

Scale bar for a and b represents $500 \mathrm{~mm}$. 


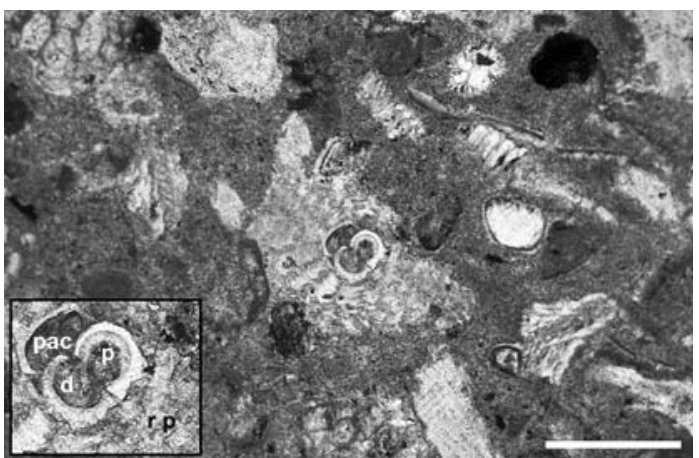

Fig. 5: Micrite-rich bioclastic packstone with an oblique equatorial section of Pseudorbitoides rutteni. Scale bar represents $500 \mathrm{~mm}$. Inset showing the embryonic chambers with the protoconch (p) and one deuteroconch (d) of similar size, and two principal auxiliary chambers ( $\mathrm{p}$ a c) unequal in size. The radial plates ( $\mathrm{r}$ p) start near the nepionic stage.

Scale bar represents $250 \mathrm{~mm}$.

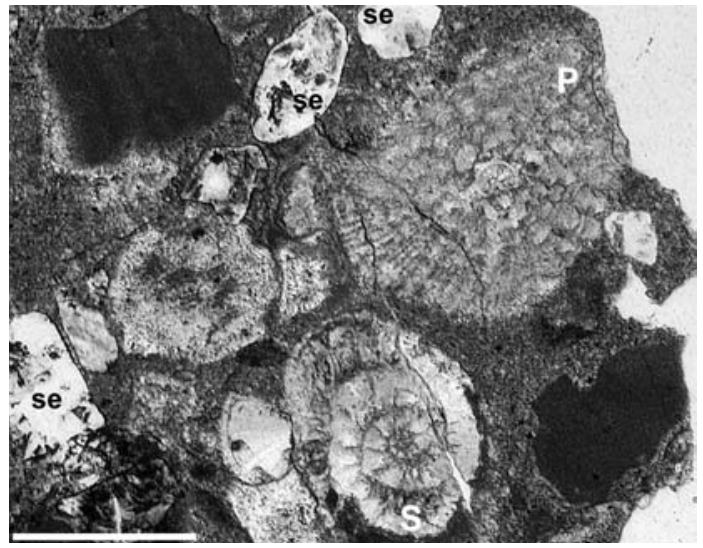

Fig. 6: Bioclastic packstone with an oblique equatorial section of Pseudorbitoides rutteni (P) and Sulcoperculina sp. (S). Note also angular and rounded serpentinite grains (se). Scale bar represents $500 \mathrm{~mm}$.

Sulcoperculina sp. Thalmann, and Sulcoperculina globosa De Cizancourt (Fig. 7). Based on these identifications, the sample is dated as Campanian-Maastrichtian.

\section{DISCUSSION}

In general, the specimens of Pseudorbitoides sp. can not be determined without an oriented section. More material is

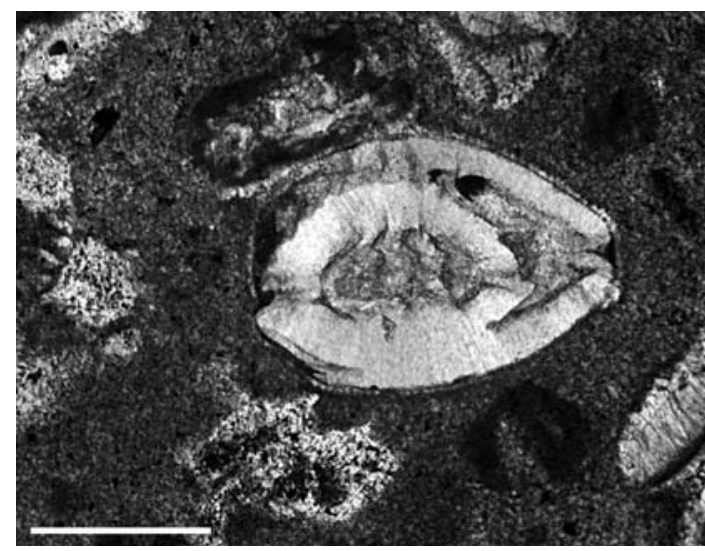

Fig. 7: Oblique vertical section of Sulcoperculina globosa. Scale bar represents $250 \mathrm{~mm}$.

necessary to make a reliable determination. The following observations are based on CL and normal transmitted light observations: the embryonic apparatus of some specimens Pseudorbitoides is megalospheric (Fig. 5) with a protoconch (p) and one deuteroconch (d) of similar size, and two principal auxiliary chambers ( $\mathrm{p}$ a c) unequal in size. Four spirals seem to extend from these auxiliary chambers (quadriserial nepiont). Near the juvenarium stage, the radial plates ( $\mathrm{r} p$ ) start and extent straight to the periphery. According to Brönnimann (1955) these characteristics were diagnostic for Pseudorbitoides rutteni. We found an uniserial fragment that can be assigned to Pseudorbitoides israelski . Both $P$. rutteni and $P$. israelski, must have coexisted However, according to Brönnimann (1955) P. rutteni appeared first late in the Campanian.

The bioclasts found in Peña Bruja are typical of a shallow water depositional environment. Probably, the microfacies is similar to the one described by Burgois et al. (1984) from isolated hills located inshore, near Playa Naranjo (Southern Santa Elena Peninsula).

\section{REFERENCES}

BAUMGARTNER, P.O., MORA, C., BUTTERLIN, J., SIGAL, J., GLACON, G., AZÉMA, J. \& BURGOIS; J., 1984: Sedimentación y paleogeografía del 
Cretácico y Cenozoico del litoral pacífico de Costa Rica.- Rev. Geol. América Central, 1: 57-136.

BRÖNNIMANN, P. 1955: Upper Cretaceous orbitoidal foraminifera from Cuba (Part III, Pseudorbitoides $\mathrm{H}$. Douvilléé, 1922).- Contrib. Cushman Foundation for Foraminiferal Res. 6: 57-76.

BURGOIS, J., AZÉMA, J., BAUMGARTNER, P.O., TOURNON, J., DESMET, A. \& AUBOIN, J., 1984 : The geologic history of the Caribbean-Cocos Plate boundary with special reference to the Nicoya Ophiolite Complex (Costa Rica) and D.S.D.P. results (Legs 67 and 84 off Guatemala : a synthesis).Tectonophysics 108 (1984): 1-32.
CHIESA, S., CONFORTINI, F. \& MADESANI, R., 1998: Geología del ACG.- Rotschildia 5(2):4-34.

MADRIGAL, R., 1982: Geología de Santa Rosa.- 56 págs. Ed. UNED, San José.

SCHMIDT-EFFING, R., 1974: El primer hallazgo de amonites en América Central Meridional y notas sobre las facies cretácicas en dicha región.- Inf. Sem. IGN 1974(1): 53-61.

TOURNON, J. \& ALVARADO, G., 1997: Mapa geológico de Costa Rica.- 79 págs. + mapa escala 1:500 000. Ed. Tecnológica, Cartago. 